\title{
Sugárterhelés az invazív kardiológiában
}

\author{
Kupó Péter, Sághy László
}

\author{
Szegedi Tudományegyetem, Szent-Györgyi Albert Klinikai Központ, \\ II. számú Belgyógyászati Klinika és Kardiológiai Központ, Szeged \\ Levelezési cím: \\ Dr. Kupó Péter \\ Szegedi Tudományegyetem, Szent-Györgyi Albert Klinikai Központ, II. számú Belgyógyászati Klinika és \\ Kardiológiai Központ, 6725 Szeged, Semmelweis utca 8.
}

Az elmúlt 20 évben az invazív kardiológia ugrásszerű fejlődésen ment keresztül. A hazai invazív kardiológiai beavatkozások száma is évröl évre növekvő tendenciát mutat. Ezen beavatkozásokat hagyományosan röntgensugárzás használata mellett végzik sugárterhet róva ezáltal nemcsak a betegekre, de a műtéteket végző személyzetre is.

Jelen közleményünkben nemzetközi irodalmi adatok alapján tekintjük át a sugárterhelés biológiai alapjait, lehetséges következményeit, az egyes invazív kardiológiai procedúratípusokra jellemző sugárterhelés mértékét, kitérve a beavatkozást végző személyzet fokozott egészségügyi kockázatára, továbbá ismertetjük a hazai jogi szabályozás elemeit az invaziv kardiológia területén dolgozók juttatásaira és kedvezményeire vonatkozóan.

Kulcsszavak: invazív kardiológia, sugárterhelés, sugárvédelem

\section{Radiation exposure in invasive cardiology}

The field of invasive cardiology has shown a significant development in the past 20 years. Invasive cardiologic procedures are becoming more and more common in everyday cardiologic care year by year. Classically these procedures are carried out with the use of X-ray, entailing radiation burden to both patients and health care providers.

Reviewing international scientific literature data, our aim was to examine the biological basics of radiation burden, its possible consequences and the level of radiation burden in each invasive cardiologic procedures. Moreover, it was our special interest to discuss the increased health risk of the staff carrying out these procedures and the Hungarian legal regulation regarding the allowances of health care providers working in this field.

Keywords: invasive cardiology, radiation exposure, radiation protection

Az elmúlt két évtizedben az invazív kardiológiai beavatkozások száma jelentősen megemelkedett és továbbra is folyamatosan emelkedő tendenciát mutat. Ezen beavatkozások hagyományosan röntgensugárzás használata mellett történnek, jelentős sugárterhet róva ezáltal nemcsak a betegekre, de a mütéteket végző személyzetre is. A mesterségesen létrehozott sugárterhelés legnagyobb hányadáért az orvosi célból történő felhasználás a felelős, ezáltal átlagosan mintegy 1,0-3,0 mSv/ fő/év effektív dózis (ED) sugárterhelést okozva, ami hozzávetőlegesen 150 mellkas-röntgenfelvétel radiológiai rizikójának felel meg (1). Bár az invazív kardiológiai beavatkozások az összes ionizáló sugárzással történő orvosi vizsgálat csupán 12\%-át teszik ki, mégis a teljes expozíció 85\%-áért felelősek (2-4).
Az ionizáló sugárzás közvetlen és közvetett hatást gyakorol az élő sejtekre. A DNS-sel, a fehérjékkel és a sejtmembránok lipidjeivel való közvetlen hatás révén direkt sejtkárosodást okozhat; vagy kölcsönhatásba lépve más molekulákkal - elsősorban a vízzel - szabadgyököket létrehozva, indirekt módon képes károsítani a sejtek különböző alkotóelemeit (5).

\section{Az ionizáló sugárzás biológiai hatásai}

Az ionizáló sugárzás biológiai hatásait sztochasztikus és determinisztikus hatásokra oszthatjuk. A determinisztikus hatások a szöveti reakciókat foglalják magukba. Ezen hatások jellemzője, hogy a sugárhatást köve- 
tően rövid időn belül megfigyelhetők, továbbá hogy a kialakuló szöveti károsodás mértéke szorosan korrelál a károsodást okozó sugárdózis nagyságával. Egy bizonyos határérték alatt (küszöbdózis) a szöveti reakciók nem jelentkeznek (6).

A sugárzás okozta sztochasztikus hatásokat a "lineáris non-treshold" modell írja le. A sztochasztikus hatások felelősek a karcinogenezisért, kialakulásukhoz általában hosszabb idő szükséges. Ezeknél a hatásoknál nincs küszöbdózis, nagyobb sugárterhelés az egészségügyi károsodás kockázatának emelkedéséhez vezet (6).

A röntgensugárzás-vezérelt beavatkozások okozta radiológiai rizikó mennyiségi jellemzésére az elnyelt dózis mérőszám szolgál, amelynek mértékegysége a Gray (Gy). Mivel az emberi szervezet szöveteit a különböző ionizáló sugárázások eltérő mértékben károsíthatják, ezért az elnyelt sugárzás okozta biológiai hatást az egyes sugárzástípusokra jellemző súlyzó tényezővel veszik figyelembe. Az így származtatott mérőszám az egyenértékdózis, amelynek mértékegysége a Sievert (Sv). Az egyenérték-dózis meghatározásához szükséges súlyzószám röntgensugarakra vonatkoztatva 1 , tehát $1 \mathrm{~Gy}$ elnyelt sugárdózis $1 \mathrm{~Sv}$ egyenértékdózisnak felel meg. Az emberi szervezet szerveinek sugárérzékenysége eltérö, a szervek különböző mértékủ sugárérzékenységét figyelembe véve az egyes szerveket ért sugárterhelést az effektív dózis megadásával fejezhetjük ki, amelynek mértékegysége szintén a Sv. Az effektív dózis méröszámot a sugárterhelésnek kitett munkavállalók sugárterhelésének monitorozására vezették be, de a betegek sugárterhelésének mérésére is széles körben használják (7).

\section{Sugárterhelés a kardiológiában}

Az invazív kardiológia területén dolgozók éves effektív dózisa az alkalmazott sugárvédelem ellenére az $5 \mathrm{mSv}$-t is elérheti, amely jelenleg a legnagyobb terhelést jelenti a klinikai medicinában. Ez tehát többszöröse mind a nukleáris medicina, mind a radiológia területén dolgozók sugárterhelésének; több évtizeden át tartó munkavégzés esetén $2 \mathrm{mSv}$ átlagos éves sugárterhelést feltételezve a daganatos megbetegedések incidenciáját 1\%-kal megemelve (8). A hosszú távú sugárexpozíció következtében az invazív kardiológusok körében bizonyítottan magasabb a bal agyféltekei tumorok kialakulásának kockázata, nők esetén emellett emelkedett a bal oldali melltumorok prevalenciája, míg minden második operátor esetében az évtizedek során katarakta alakul ki (9-11).

A gyakori, ionizáló sugárzás használatával járó kardiológiai procedúrák - perkután koronária-intervenciók, miokardiális perfúziós képalkotó vizsgálat, pitvarfibrilláció miatt végzett katéterabláció - átlagosan akár mintegy $15 \mathrm{mSv}$ effektív dózis sugárterheléssel járhatnak (1. táblázat), de a különböző kardiológiai diagnosztikus és terápiás eljárások között nagyfokú variancia mutatkozik a sugárterhelést tekintve.

\section{Elektrofiziológiai beavatkozások}

Az elektrofiziológiai (EP) procedúrák során használt sugáridő 95 százaléka a katéterek pozícionáláshoz szükséges, ám mindez csak a teljes sugárterhelés kevesebb, mint feléért felelös (7). Válogatott esetekben mozgókép-felvételek készülnek (pl. cryoballonnal történő pulmonalis vénaizolációk esetén), amelyek - bár a teljes expozíciós idő csak 5 százalékát teszik ki - az EP-procedúrák sugárterhelésének döntő részét adják. A sugárterhelés tág határok között mozog a ritmuszavar típuságtól függően (1. táblázat). Az operátort ért átlagos effektív dózis egy brit tanulmány alapján 40-60 $\mu S v$ EP beavatkozások esetén (12). Az elmúlt évtizedben végbement technológiai fejlödésnek köszönhetöen intrakardiális echocardiográfia és háromdimenziós elektroanatómiai térképezőrendszerek valós idejü alkalmazása mellett a beavatkozások többsége minimáls sugárterheléssel, illetve akár fluoroszkópia használata nélkül is biztonsággal elvégezhető.

\section{Implantációs és extrakciós procedúrák}

Az egy- és kétüregű pacemaker-beültetésen áteső betegek ért sugárterhelés 1,4-1,7 mSv között mozog (13). A szórt sugárzás sugárvédelmi pajzzsal történő árnyékolása sokkal nehezebben kivitelezhető az ablációkhoz képest, így fokozott sugárterhelést róva a mütétet végző operatőrre és asszisztenciára. Biventrikuláris készülékek beültetésekor a bal kamrai elektróda pozícioná-

1. TÁBLÁZAT. Diagnosztikus és terápiás vizsgálatok átlagos effektív dózisai

\begin{tabular}{|c|c|c|}
\hline & $\begin{array}{l}\text { Átlagos } \\
\text { effektív } \\
\text { dózis } \\
\text { (mSv) }\end{array}$ & $\begin{array}{l}\text { Hány mell- } \\
\text { kas-röntgen } \\
\text { felvétellel } \\
\text { ekvivalens? }\end{array}$ \\
\hline Mellkas-röntgenfelvétel, PA & 0,02 & 1 \\
\hline $\begin{array}{l}64 \text { szeletes koronária } \\
\text { CT-vizsgálat }\end{array}$ & 16 & 800 \\
\hline Koronária-angiográfia & 7 & 350 \\
\hline Perkután koronáriainterenció & 15 & 750 \\
\hline $\begin{array}{l}\text { Diagnosztikus invazív } \\
\text { elektrofiziológiai vizsgálat }\end{array}$ & 3 & 150 \\
\hline $\begin{array}{l}\text { Radiofrekvenciás katéterabláció } \\
\text { - pulmonalis vénaizoláció }\end{array}$ & 15 & 750 \\
\hline $\begin{array}{l}\text { Kétüregü pacemaker/ } \\
\text { ICD-beültetés }\end{array}$ & 1,6 & 80 \\
\hline $\begin{array}{l}\text { Biventrikuláris pacemaker/ } \\
\text { ICD-beültetés }\end{array}$ & 22 & 1100 \\
\hline $\begin{array}{l}\text { Invazív kardiológiai laborban } \\
\text { dolgozók éves sugárexpozíciója }\end{array}$ & 5 & 250 \\
\hline Természetes háttérsugárzás & 2,4 & 120 \\
\hline
\end{tabular}

Röviditések: CT: komputertomográfia, ICD: implantálható kardioverter defibrillátor, PA: posteroanterior. Forrás: 1, 3, 8, 13, 14. 
Determinisztikus hatás

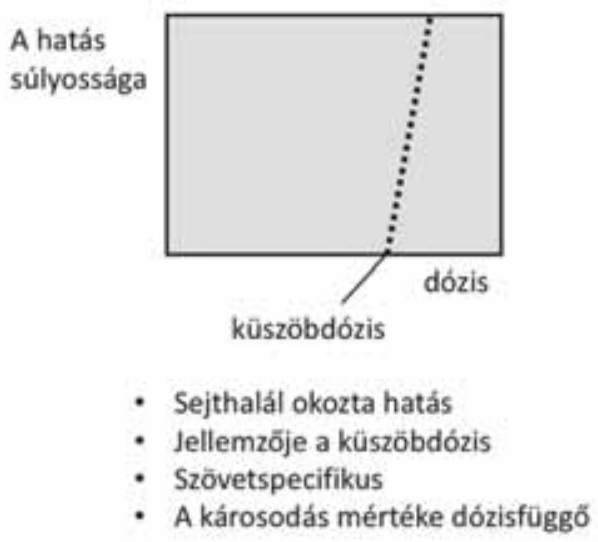

Sztochasztikus hatás

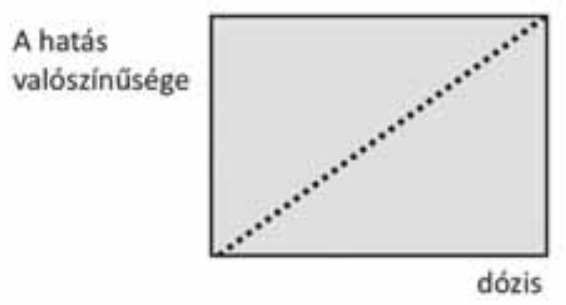

- Sejtkárosodás (DNS-károsodás) okozta hatás

- Nincs küszöbdózis

- A hatás súlyossága nem dózisfüggő

- Növekvő dózis a hatás megjelenésének valószínüségét emeli

1. ÁBRA. Determinisztikus és sztochasztikus sugárhatás. Forrás: IAEA ingyenes képzési dokumentumok https://rpop.iaea.org/ RPOP/RPoP/Content/AdditionalResources/Training/1_TrainingMaterial/Radiotherapy.htm

lásához kontrasztanyag alkalmazására van szükség a sinus coronarius anatómiájának ábrázolásához, ilyenkor pedig a röntgenátvilágítás helyett mozgókép kerül rögzítésre, akár több projekcióból is, ami szintén hozzájárul a sugárterhelés jelentős emelkedéséhez. Mindemelett CRT-beavatkozások esetén az operatőr az alkalmazott projekciók miatt technikai okokból teljesen kitett a szórtsugárzással összefüggő expozíciónak (14). Elektróda-extrakciók esetén az eltávolítandó elektródákon történő manipuláció vizualizációja javarészt fluoroszkópia vezérelt, így a gyakran órákon át tartó maratoni beavatkozások az invazív kardiológia legnagyobb sugárterheléssel járó procedúrái közé tartoznak.

\section{Intervencionális kardiológiai beavatkozások}

Bár az elmúlt években a diagnosztikus szívkatéteteres vizsgálatok számának növekedése lelassult, hazánkban is egyre elterjedtebbé és gyakoribbá váltak a komplex intervencionális kardiológiai beavatkozások (krónikus totális okklúziók megnyitása, transzkatéteres billentyüimplantációk, ballonos aortabillentyü-valvuloplasztika). A komplex léziók intervenciója az összes intervencionális beavatkozás közel felét teszik ki, mindemellett az arteria radialis behatolásból végzett vizsgálatok száma az elmúlt időszakban megtízszereződött $(15,16)$. Mind a komplex esetek, mind az arteria radialis behatolásból végzett beavatkozások hosszabb procedúra- és ezáltal hosszabb sugáridővel járnak, ezáltal megnövekedett sugárterhelést okozva. Egy multicentrikus vizsgálatban, több mint 57000 invazív hemodinamikai beavatkozás adatait elemezve kimutatták, hogy a centrumok gyakorlottsága is meghatározó: tapasztaltabb hemodinamikai laborok esetén alacsonyabb sugárdózisokat regisztráltak, kisebb volumenü laborokkal összehasonlítva (17).

Karrierje során, évtizedek alatt, a napi rendszerességgel diagnosztikus és terápiás invazív kardiológiai beavat- kozásokat végző kardiológusok sugárterhelése a 200 mSv-t is elérheti amely 10000 mellkas-átvilágítás sugárterhelésének felel meg, jelentős egészségügyi kockázatot jelentve (18). Mindemellett a sugárvédelmi ólomköpenyek viselése növeli a muszkuloszkeletális fájdalom és betegségek kialakulásának kockázatát, amelynek prevalenciája az invazív kardiológusok körében akár 60$70 \%$ is lehet, korai munkaképesség-csökkenést, adott esetben akár rokkantságot okozva $(11,19,20)$.

\section{Sugárvédelem, sugárveszélyes munkahelyen dolgozók kedvezményei}

A doziméter, vagy dózismérő szolgál a szervezetet ért sugárterhelés hosszú távú mértékének monitorozására. A sugárterhelt környezetben dolgozókra vonatkoztatott dóziskorlátokat a Nemzetközi Sugárvédelmi Szervezet (International Council on Radiation Protection, ICRP) ajánlásait figyelembe véve az Országos Atomenergia Hivatal (OAH) állapítja meg: a foglalkozási sugárterhelésre vonatkozó effektív dóziskorlát évi 20 $\mathrm{mSv}$. Indokolt esetben az OAH eseti jelleggel egy-egy évben ennél nagyobb, de legfeljebb 50 mSv nagyságú effektív dózist is engedélyezhet, amennyiben bármely egymást követő öt évben - azokat az éveket is ideértve, amikor a korlátot meghaladták - az éves átlagos dózis nem haladja meg a 20 mSv értéket (487/2015. (XII. 30.) Korm. rendelet).

Bár az ICRP két személyi doziméter használatát javasolja személyenként - egyet a sugárvédelmi ruházat alatt, a törzsön viselve, egyet pedig a nyak, vagy a bal váll magasságában hordva a sugárköpeny felett - a jelenlegi magyarországi gyakorlatban személyenként egy doziméter kerül biztosításra (7). Két személyi doziméter kiadása esetén pontos képet kaphatunk a sugárvédelmi munkaruházattal közvetlenül nem védett felületeket- bőr, szemlencse, koponya - effektív sugárdózisát 
tekintve, ez a gyakorlat azonban hazánkban még nem honosodott meg.

Az ionizáló sugárzás egészségkárosító hatásai miatt az invazív kardiológia területén dolgozók az alábbi törvényben szabályozott juttatásokra és kedvezményekre jogosultak:

- Iletménypótlék: a közalkalmazott pótlékra jogosult, ha foglalkoztatására munkaideje legalább felében jogszabályban meghatározott egészségkárosító kockázatok között kerül sor (1997. évi LVI. törvény 6.§). Az invazív kardiológián dolgozókat a pótlékalap 120\%-át kitevő illetménypótlék illeti meg, ami jelenleg bruttó 24000 Ft (356/2008(XII.31) Korm. rendelet).

- Munkaidő-kedvezmény: munkaidő-kedvezményre jogosult és így a teljes napi munkaidejéből 6 órát kell munkahelyén töltenie azon közalkalmazottnak, aki munkahelyén legalább napi 3 órán át sugárártalomnak kitett (356/2008 (XII.31) Korm. rendelet).

- Pótszabadság: az ionizáló sugárzásnak kitett munkahelyen naponta legalább 3 órát töltő munkavállalót évente 5 munkanap pótszabadság illeti meg. Ilyen munkahelyen legalább 5 év eltöltése után évente 10 munkanap pótszabadság jár (1992. évi XXXIII. törvény).

A fenti törvényeket a magyarországi invazív kardiológiai tevékenységek megszületése, illetve rutinná válása előtti időszakban a hagyományos radiológiai szakmára vonatkozóan hozták. Azóta azonban ugrásszerű fejlődés és változás következett be a magyar hemodinamika és elektrofiziológia területén: számos mütő nyílt, nőtt a beavatkozások száma és komplexitása - ezeknek velejárójaként a dolgozókat ért sugárterhelés is fokozódott. Ebben a közegben már nehezen értelmezhető pl. a „legalább napi 3 órán át” fennálló sugárártalom kifejezés, lévén, hogy még az invazív kardiológiában is - ahol a legnagyobb a dolgozókat ért sugárterhelés - extrém ritka esetekben fordul elő egy napra és egy dolgozóra vetítve 180 percnyi sugáridő, ami ezen szakmákban alkalmazott átvilágítási időt jelentené. A sugáridőnél relevánsabb lenne az effektív sugárdózis paraméter használata.

Mindemellett, a magyarországi gyakorlatban a munkaidő kedvezményt hagyományosan a radiológia területén dolgozó munkavállalók esetén alkalmazzák, holott a jogszabály alapján a sugárterhelésnek - a radiológiához viszonyítva - sokszorosan kitett invazív kardiológiai dolgozók is jogosultak lennének rá. A jelenlegi általános humánerőforrás-helyzetet alapul véve mindez az invazív kardiológia területén nehezen valósítható meg.

A szerzők véleménye szerint paradigmaváltásra van szükség a magyar egészségügynek ezen a területén is: aktualizált, humánus és európai szabályozásra, anyagi és nem anyagi természetű elismerésre a medicina sugárártalmainak és az ehhez társuló jelentős egészségkárosító kockázatoknak súlyosan, legsúlyosabban kitett munkavállalók, az invazív kardiológia területén dolgozók megbecsülésére.
Irodalom

1. Mettler FA, Bhargavan M, Faulkner K, et al. Radiologic and Nuclear Medicine Studies in the United States and Worldwide: Frequency, Radiation Dose, and Comparison with Other Radiation Sources-1950-2007. Radiology 2009; 253: 520-31. doi: 10.1148/radiol.2532082010

2. Amis ES, Butler PF, Applegate KE, et al. American College of Radiology White Paper on Radiation Dose in Medicine. J Am Coll Radiol 2007 4: 272-84. doi: 10.1016/j.jacr.2007.03.002

3. Gerber TC, Jeffrey Carr J, Arai AE, et al. Ionizing radiation in cardiac imaging: A science advisory from the American Heart Association Committee on cardiac imaging of the council on clinical cardiology and committee on cardiovascular imaging and intervention of the council on cardiovascular radi. Circulation 2009; 119: 1056-1065. doi: 10.1161/CIRCULATIONAHA.108.191650

4. Picano $E$, Vano $E$. The radiation issue in cardiology: The time for action is now. Cardiovasc Ultrasound 2011; 9: 1-13. doi: 10.1186/1476-7120-9-35 5. Hall EJ, Giaccia AJ. Radiobiology for the radiologist: Seventh edition 2012. 6. International Commission on Radiological Protection. The 2007 Recommendations of the International Commission on Radiological Protection. ICRP Publication 2007; 103. Ann ICRP. doi: 10.1016/j. icrp. 2004.12.002

7. Heidbuchel H, Wittkampf FHM, Vano $E$, et al. Practical ways to reduce radiation dose for patients and staff during device implantations and electrophysiological procedures. Europace 2014; 16: 946-964. doi: 10.1093/europace/eut409

8. Venneri L, Rossi F, Botto N, et al. Cancer risk from professional exposure in staff working in cardiac catheterization laboratory: insights from the National Research Council's Biological Effects of Ionizing Radiation VII Report. Am Heart J 2009; 157: 118-24. doi: 10.1016/j. ahj.2008.08.009 9. Buchanan GL, Chieffo A, Mehilli J, et al. The occupational effects of interventional cardiology: Results from the WIN for safety survey. Eurolntervention 2012; 8: 658-63. doi: 10.4244/EIJV8I6A103

10. Roguin A, Goldstein J, Bar O, Goldstein JA. Brain and neck tumors among physicians performing interventional procedures. Am J Cardiol 2013, 111: 1368-1372. doi: 10.1016/j.amjcard.2012.12.060

11. Orme NM, Rihal CS, Gulati R, et al. Occupational health hazards of working in the interventional laboratory: A multisite case control study of physicians and allied staff. J Am Coll Cardiol 2015; 65: 820-826. doi: 10.1016/j.jacc.2014.11.056

12. Efstathopoulos EP, Katritsis DG, Kottou S, et al. Patient and staff radiation dosimetry during cardiac electrophysiology studies and catheter ablation procedures: A comprehensive analysis. Europace 2006; 8: 443-8. doi: 10.1093/europace/eul041

13. Tsapaki V, Christou A, Spanodimos S, et al. Evaluation of radiation dose during pacemaker implantations. Radiat Prot Dosimetry 2011; 147 75-7. doi: 10.1093/rpd/ncr267

14. Butter C, Schau T, Meyhoefer J, et al. Radiation Exposure of Patient and Physician during Implantation and Upgrade of Cardiac Resynchronization Devices 2010; 33: 1003-1012. doi: 10.1111/j.15408159.2010.02765.x

15. Fazel R, Curtis J, Wang $Y$, et al. Determinants of fluoroscopy time for invasive coronary angiography and percutaneous coronary intervention Insights from the NCDR $®$. Catheter Cardiovasc Interv 2013; 82: 1091105. doi: $10.1002 /$ ccd. 24996

16. Feldman DN, Swaminathan RV, Kaltenbach LA, et al. Adoption of radial access and comparison of outcomes to femoral access in percutaneous coronary intervention an updated report from the national cardiovascular data registry (2007-2012). Circulation 2013; 127: 2295-306. doi: 10.1161/CIRCULATIONAHA.112.000536

17. Simard T, Hibbert B, Natarajan MK, et al. Impact of center experience on patient radiation exposure during transradial coronary angiography and percutaneous intervention: A patient-level, international, collaborative, multi-center analysis. J Am Heart Assoc 2016; 5: 1-7. doi: 10.1161/ JAHA.116.003333

18. Picano E, Vano E, Domenici L, et al. Cancer and non-cancer brain and eye effects of chronic low-dose ionizing radiation exposure. BMC Cancer. 2012. doi: 10.1186/1471-2407-12-157

19. Andreassi MG, Piccaluga E, Guagliumi G, et al. Occupational health risks in cardiac catheterization laboratory workers. Circ Cardiovasc Interv 2016; 9: 1-9. doi: 10.1161/CIRCINTERVENTIONS.115.003273

20. Rees CR, Duncan BWC. Get the Lead off Our Backs! Tech Vasc Interv Radiol 2018; 21: 7. doi: 10.1053/j.tvir.2017.12.003 